\title{
Selection intensity for milk yield in 1970-1977 in the Finnish Ayrshire
}

\author{
U. B. LINDSTRÖM \\ Agricultural Research Centre, Institute of Animal Breeding, SF-01300 Vantaa 30
}

\begin{abstract}
Selection differentials for sires and dams of bulls taken into AI use in 1970-1977, as well as for sires used in AI, were combined with an estimate of the quality of dams of female replacements to calculate the (predicted) genetic change in milk yield in the Ayrshire breed. In the period the average annual genetic gain was $0.97 \%$ of the mean yield, in the last three years it was c. $1.1 \%$. The average generation interval was 6.8 years; 8.7 years for the bull sires, 7.4 years for the bull dams and 6.4 years for the cow sires. The bull sires accounted for $42 \%$, the bull dams for $37 \%$ and the cow sires for only $12 \%$ of the total genetic gain. A more rational use of progeny tested and young bulls, combined with a reduction of the generation interval of $15 \%$, could easily have increased the genetic progress by $20 \%$.
\end{abstract}

\section{Introduction}

In the past ten years serious efforts have been made in all Scandinavian countries to develop efficient A. I. dairy cattle breeding programmes (LINDHÉ 1968; Maijala 1969; Petersen et al. 1974, SkJervold 1967). These programmes are all - to a smaller or greater extent - based on the studies by RoBERTSON and Rendel (1950) and SkJervold and Langholz (1964 a, 1964 b). All suggested breeding schemes indicate possibilities of achieving $1.2-1.6 \%$ annual genetic gains in milk yield by an optimal selection and use of the parents of the next generation. However, even if prerequisites for carrying out efficient breeding work exist, these do not guarantee that the actual selection intensity and use of the breeding animals is satisfactory. Therefore it is necessary, with regular intervals, to calculate the selecation differentials achieved in the practised breeding schemes. The main purpose of the present study is to calculate the intensity of selection for milk yield in the period 1970-76 for the Ayrshire sires and dams used in A. I. (Artificial Insemination) breeding. Comparisons with theoretical expectations and previous studies will also be made.

\section{Material and methods}

The material was collected from the annual reports of the Central Association of A. I. Societies (ANon. 1970-77). Information was tabulated only for those bulls (sons) who were actually used in A. I. The production information

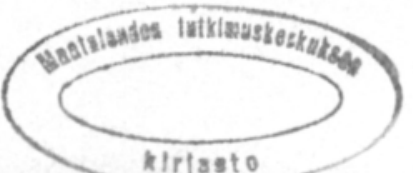


Table 1. Outline of material of present study.

\begin{tabular}{|c|c|c|c|c|}
\hline & Year & $\begin{array}{l}\text { No. of sire-son } \\
\text { and dam-son pairs }\end{array}$ & $\begin{array}{l}\text { No. of progeny } \\
\text { tested bulls }\end{array}$ & $\begin{array}{l}\text { No. of young } \\
\text { bulls } \mathbf{x x}\end{array}$ \\
\hline 1970 & n.............. & $93 x$ & 286 & 669 \\
\hline 1971 & n............. & $121^{x}$ & 251 & 574 \\
\hline 1972 & ................ & 180 & 355 & 610 \\
\hline 1973 & ................ & (31) & 399 & 643 \\
\hline 1974 & n................ & (21) & 452 & 719 \\
\hline 1975 & ................. & $(46)$ & 472 & 780 \\
\hline 1976 & n............... & (56) & 522 & 762 \\
\hline 1977 & ................. & (41) & 525 & 687 \\
\hline Sum & n............. & 1400 & 3262 & 5444 \\
\hline
\end{tabular}

x Material represents sample of all pairs due to incomplete data files

xx Testing of young bulls spead out over $1-3$ years, so many bulls appear in several years

$\boldsymbol{\Delta}$ No. of bull calves with foreign sire (see text for explanation).

on the sires and dams was collected from the official progeny test results and the official milk recording statistics. For each part of the selection process, sire to son, sire to daughter and dam to son, genetic selection differentials were calculated. The material is outlined in Table 1. The bull sire's genetic selection differential $\left(\mathrm{S}_{\mathrm{s}}\right)$ was estimated from:

where,

$$
\mathrm{S}_{\mathrm{s}}=2(\mathrm{P}-\overline{\mathrm{X}})
$$

$\mathrm{P}=$ bull's corrected official progeny test for milk yield (corrected for age, calving season and No. of daughters).

$\overline{\mathrm{X}}=$ average of (corrected) progeny tests for milk yield for all bulls in a particular year.

A detailed description of the progeny testing system in Finland is given by Lindström et al. (1973). According to a recent study (Lindström and SirKKomaA 1977), the progeny tests seem to be fairly accurate in Finland.

In recent years a limited number of bull sires from abroad, 8 from the Norwegian Red Cattle and 6 from North American and English Ayrshires, have been used on our Finnish Ayrshire cows for production of bull calves. The original progeny test $(\mathrm{OP})$ of these foreign bull sires was transformed into a Finnish progeny test (FP) by the formula:

$$
\mathrm{FP}=\left(\mathrm{OP}-\overline{\mathrm{x}}_{\mathrm{OP}}\right) \frac{\sigma \mathrm{FP}}{\sigma \mathrm{OP}}
$$

where,

$\overline{\mathrm{X}}_{\mathrm{OP}}=$ average of original progeny test

$\sigma \mathrm{FP}=$ standard deviation of Finnish progeny test

$\sigma \mathrm{OP}=$ standard deviation of original progeny test

Although the breeding aims for the English and North American Ayrshires may to some extent differ from those of the Finnish Ayrshire, the inclusion of these foreign bull sires in the material should not cause much of an error. The inclusion of the Norwegian bull sires, on the other hand, is more doubtful, but as the breed is related to the Finnish Ayrshire and as there has been a 
continuous exchange of semen between the two populations, the procedure was considered justified. In all 213 of the 1400 bull calves (15\%) had a foreign sire (see Table 1), almost equally divided between the Norwegian Red and the Ayrshire sires.

For each sire his most accurate progeny test result, i.e. the one based on the largest number of daughters, was used.

The bull dam's genetic selection differential $\left(\mathrm{S}_{\mathrm{D}}\right)$ was calculated from:

$$
S_{D}=(R-A) \frac{0.2 n}{1+(n-1) 0.4}+(H-B) 0.08
$$

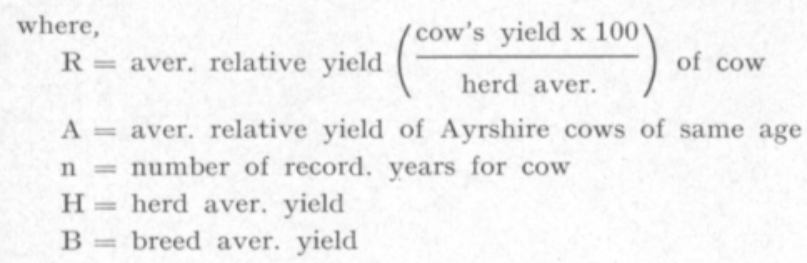

The heritabilities used, 0.2 for the relative milk yield and 0.08 for the herd differences, are in accordance with the previous study (LINDSTRöm 1969). The former estimate still seems appropriate (Lindström and SirkKomaA 1977), whereas we have no reliable figures for the latter. The low value of 0.08 has, however, only a slight influence on the overall selection differential.

The selection differential in the path sire to daughter $\left(\mathrm{S}_{\mathrm{C}}\right)$ was estimated from:

$$
\mathrm{S}_{\mathrm{C}}=\frac{\sum[2 \mathrm{~N}(\mathrm{P}-\overline{\mathrm{X}})] \cdot \mathrm{S}}{\mathrm{T}}
$$

where,

$\mathrm{P}$ and $\overline{\mathrm{X}}$ as for the bull sires

$\mathrm{N}=$ No. of pregnancies (60 day snon returns $)$ by sire in particular year

$\mathrm{T}=$ total number of pregnancies by progeny tested A.I. sires in same year

$\mathrm{S}=$ share of all pregnancies by progeny tested bulls

This gives a weighted selection differential corresponding to the actual influence of a particular bull in a given year. The generation intervals were calculated from the differences in birth dates between the parents and their progeny. For the cow sires the intervals were weighted by the appropriate number of pregnancies (non returns) of each sire; in this case basing the calculations on the results for all sires (progeny tested and young).

In order to calculate the annual genetic change (sum of selection differentials divided by sum of generation intervals) a genetic selection differential of 2.1 relative milk units (= percent) for the dams of female replacements was assumed. This is the actual differential found in my earlier study (Lindström 1969), and there are no indications that the selection intensity in this path should have changed noticeably since then. The generation interval for the dams of female replacements was taken as 4.5 years, in accordance with (ANON. 1974). For a more detailed description of the calculations of selection differentials, generation intervals and correction factors reference is made to my earlier paper (LINDSTRöm 1969) the procedures of which are mainly followed. 
Table 2. Genetic selection differentials and generation intervals for bull sires.

\begin{tabular}{|c|c|c|c|}
\hline & Year & $\begin{array}{l}\text { Rel. milk yield } \\
\begin{array}{c}(=\% \text { of aver. }) \\
\pm \mathrm{SE}\end{array}\end{array}$ & $\begin{array}{c}\text { Generation interval } \\
\text { years } \\
\pm \mathrm{SE}\end{array}$ \\
\hline 1970 & ............. & $10.32 \pm 0.41$ & $8.18 \pm 0.11$ \\
\hline 1971 & ............ & $8.82 \pm 0.29$ & $8.13 \pm 0.10$ \\
\hline 1972 & ............. & $9.33 \pm 0.28$ & $9.20 \pm 0.18$ \\
\hline 1973 & ............. & $9.89 \pm 0.24$ & $9.69 \pm 0.14$ \\
\hline 1974 & ............. & $10.58 \pm 0.28$ & $9.20 \pm 0.18$ \\
\hline 1975 & n........... & $13.41 \pm 0.29$ & $8.01 \pm 0.16$ \\
\hline 1976 & ............. & $14.84 \pm 0.43$ & $8.04 \pm 0.21$ \\
\hline 1977 & .............. & $13.30 \pm 0.34$ & $8.51 \pm 0.19$ \\
\hline \multicolumn{2}{|c|}{ Av. ............ } & $11.47 \pm 0.10$ & $8.96 \pm 0.08$ \\
\hline
\end{tabular}

\section{Results and discussion}

\section{Bull sires}

It seems appropriate to give the results for the three paths of the selection process studied separately. Table 2 . outlines the selection differential and generation interval for the bull sires. On the average the sires of A. I. bull calves have been fairly carefully selected, the genetic selection differential being 11.5 relative milk units. Especially in the last three years the selection of bull sires has been much more efficient than in the $1960 \mathrm{~s}$, when the genetic selection differential was only about 8 relative milk units (LindSTRöm 1969). The differentials noted in the present study correspond, on an average, to a selection intensity (i) of about $20 \%$ calculated from:

$\mathrm{i}=\frac{\mathrm{I}_{\mathrm{G}}}{\mathrm{r}_{\mathrm{IG}} \cdot \sigma_{\mathrm{G}}}$ where $\mathrm{I}_{\mathrm{G}}=11.47, \mathrm{r}_{\mathrm{IG}}=0.9$ (accuracy), and $\sigma_{\mathrm{G}}=9 \%$ (genetic stand. dev.).

In the last few years the selection intensity corresponds to the approval of about the best $10 \%$ of the bulls as sires of the next generation of young bulls. Thus, even if a noticeable improvement of the genetic quality of the bull sires has occurred, the selection can still be made more efficient.

The generation interval in the sire-son path varies between 8 and 9.7 years and is thus surprisingly long. Compared to the period $1961-66$ almost no improvement has taken place. Also in comparison with the recent study by SYRSTAD (1974 a), where the sire-son generation interval was 6.2 years, the present figures are high. The main reasons for the long generation interval are probably:

1. The inefficient use of (too many) young bulls in recorded herds, resulting in a long waiting time before the first progeny test is available;

2. The small number of daughters in the first progeny test, postponing the final decision regarding which bulls to use as bull sires;

3. The use of the same (old) bulls as sires for several years. 
Table 3. Genetic selection differentials and generation intervals for cow sires.

\begin{tabular}{|c|c|c|c|c|c|}
\hline & Year & $\begin{array}{l}\text { Unweighted rel. } \\
\text { milk yield ( } \% \text { of } \\
\text { aver.) }\end{array}$ & $\begin{array}{l}\text { Proportion of all } \\
\text { monreturned cows? }\end{array}$ & $\begin{array}{l}\text { Weighted sel. } \\
\text { diff. } \pm \mathrm{SE}\end{array}$ & $\begin{array}{l}\text { Generation } \\
\text { interval, } \\
\text { years } \pm \mathrm{SE}\end{array}$ \\
\hline 1970 & ........... & 6.35 & .583 & $3.70 \pm .27$ & $7.02 \pm .30$ \\
\hline 1971 & ............ & 6.23 & .584 & $3.64 \pm .31$ & $7.13 \pm .34$ \\
\hline 1972 & ............. & 5.84 & .603 & $3.52 \pm .32$ & $6.95 \pm .31$ \\
\hline 1973 & ............. & 5.58 & .583 & $3.25 \pm .32$ & $6.53 \pm .27$ \\
\hline 1974 & .............. & 5.74 & .564 & $3.24 \pm .34$ & $6.31 \pm .25$ \\
\hline 1975 & ............. & 5.44 & .510 & $2.77 \pm .32$ & $5.98 \pm .24$ \\
\hline 1976 & (n........... & 4.63 & .496 & $2.30 \pm .33$ & $5.85 \pm .23$ \\
\hline 1977 & ........... & 4.24 & .505 & $2.13 \pm .31$ & $5.75 \pm .24$ \\
\hline Av. & .......... & 5.46 & .564 & $3.04 \pm .09$ & $6.40 \pm .10$ \\
\hline
\end{tabular}

In addition, the use of rotational breeding, with the Ayrshire population split into 3 groups, has forced the A.I. studs to use several older bulls in order to satisfy the need for semen of satisfactory genetic merit.

\section{Cow sires}

The genetic selection differentials for the cow sires (weighted by the appropriate shares of the pregnancies) as well as the corresponding generation intervals are given in Table 3. On an average the genetic quality of the cow sires is only about $1 / 3$ of that of the bull sires. Due to the much heavier semen demand the selection differentials for the cow sires are, naturally, lower than for the bull sires. However, the observed (unweighted) differentials correspond to a selection intensity of only about 1 out of 2 tested, and are not much higher than those noted by Lindström (1969).

According to theoretical calculations, e.g. Lindhé (1968) and Petersen et al. (1974), it should be possible to obtain a selection intensity of 7 to $12 \%$ in the path sire to daughter when using frozen semen storage. The main reason why the intensity in Finland is lower lies with the splitting up of the population in subunits. There is a total of 6 A.I. studs, each practising rotational breeding with three groups. In practise this means that even if enough semen of satisfactory quality is available in the whole of the country, an A.I. stud will usually prefer to use semen from its own bulls although those may genetically be inferior to those of other studs. The rotational breeding again forces the studs to use more bulls than required if the Ayrshire breed could be treated as one population.

With regard to the generation interval no great changes have occurred in comparison with the 1960 s. In the early 1970 s the generation interval was in fact somewhat longer than in $1961-66$, but in recent years it has stabilised around 6 years. This is approximately the same as noted by SyRSTAD (1974 a). By increasing the overall usage of young ( $1-2 \mathrm{yr}$ ) bulls to $40 \%$, and using the semen of progeny tested bulls within one year of the test result, the generation interval could be decreased to about 5 years. 
Table 4. Genetic selection differentials and generation intervals for bull dams.

\begin{tabular}{|c|c|c|c|}
\hline & Year & $\begin{array}{c}\text { Rel milk yield } \\
(=\% \text { of aver. }) \\
\pm \mathrm{SE}\end{array}$ & $\begin{array}{c}\text { Generation } \\
\text { interval years } \\
\pm \mathrm{SE}\end{array}$ \\
\hline 1970 & ............ & $9.81 \pm 0.37$ & $9.23 \pm 0.29$ \\
\hline 1971 & ........... & $9.45 \pm 0.27$ & $8.59 \pm 0.27$ \\
\hline 1972 & ............ & $9.92 \pm 0.32$ & $8.52 \pm 0.22$ \\
\hline 1973 & ............ & $9.47 \pm 0.26$ & $7.16 \pm 0.21$ \\
\hline 1974 & ............ & $9.59 \pm 0.23$ & $7.07 \pm 0.20$ \\
\hline 1975 & ........... & $9.66 \pm 0.23$ & $6.65 \pm 0.16$ \\
\hline 1976 & n.......... & $9.95 \pm 0.29$ & $6.71 \pm 0.22$ \\
\hline 1977 & ........... & $10.24 \pm 0.28$ & $6.92 \pm 0.20$ \\
\hline Av. & ........... & $9.85 \pm 0.12$ & $7.41 \pm 0.05$ \\
\hline
\end{tabular}

\section{Bull dams}

The genetic selection differentials and generation intervals are given in Table 4. The differentials for the bull dams are approximately at the same level as those for the bull sires, indicating that the selection has been fairly efficient. Assuming an accuracy of 0.6 (average of 4 years production) and a genetic standard deviation of $9 \%$ of the average yield, the noted selection differentials correspond to an intensity of selection of $8-10 \%$ of the best cows as bull dams. This is slightly lower than noted for the period 1961-66, the main reasons probably being a somewhat greater emphasis on the absolute milk yields (at the expense of the relative yields) and a more widespread approval of young cows as dams, resulting in a somewhat lower overall accuracy of selection.

With regard to the generation interval a desirable decrease has taken place. In the last few years the bull dams have, on average, been some two years younger than in the $1960 \mathrm{~s}$. It should, however, still be possible to decrease the average age of the dams to 5.5-6.0 years without noticeable loss in accuracy.

\section{Annual genetic progress}

Fig. 1. outlines the expected annual genetic gain in milk yield. For comparison the corresponding results for the period $1961-66$ are given. The average (predicted) change in the whole period $1970-77$ is $0.97 \%$, with a change of c. $1.1 \%$ in the last three years. These results indicate that especially in recent years the selection efficiency has improved compared to the 1960 s. The predicted progress is in good agreement with recent studies elsewhere, see e.g. Averdunk and Lederer (1974), Hargrove and Legates (1971), Hausman (1968), Johnson et al. (1976), Powell and Freeman (1974), RüEgSEger (1975), ŠILER and ŠEREdA (1974), Syrstad (1974a), where the genetic change in milk yield usually has varied between $40-80 \mathrm{~kg}$ (or $0.8-1.2 \%$ ) per year. Much lower estimates have, however, also frequently been noted, e.g. ShaEffer et al. (1975) and Syrstad (1974 b).

Fig. 2. depicts the contribution of the various paths of the selection process to the overall genetic gain. In comparison the figures of SYRSTAD (1974 a) 
Fig. 1. Predicted genetic gain for milk production.

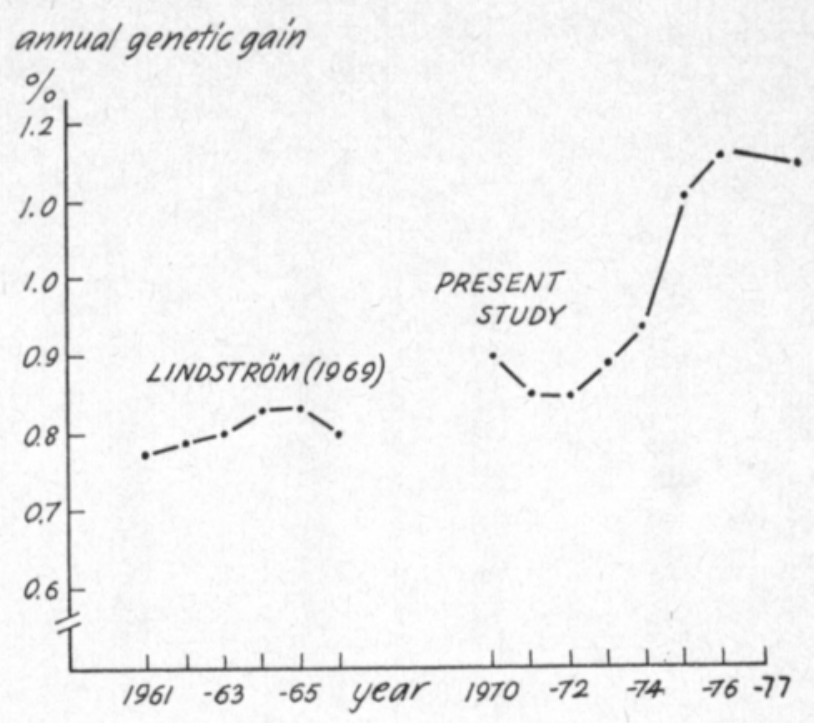

Fig. 2. Relative contribution to total genetic gain by the various groups of parents.

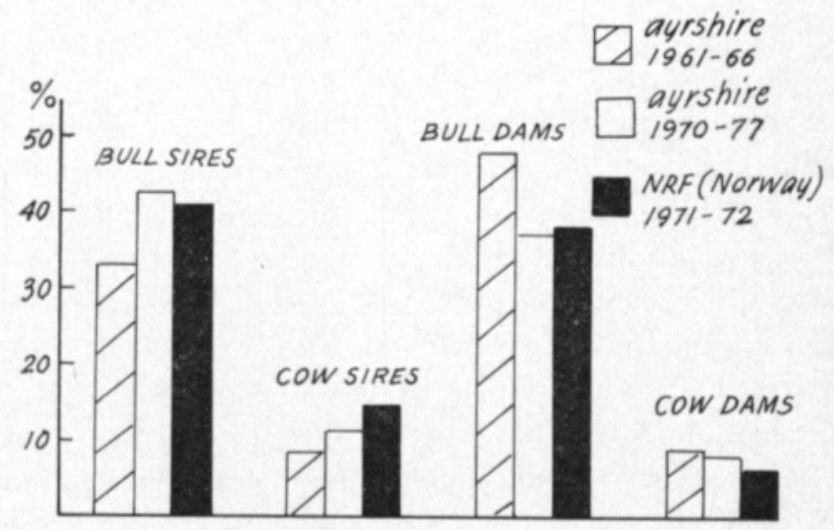

are also given. Our results are in good agreement with the Norwegian ones, with the bull sires accounting for $42 \%$, the bull dams for $37 \%$ and the cow sires for only $12 \%$ of the overall progress. The selection of cow sires has been more efficient in Norway, almost certainly because of the more rational breeding work carried out in one population. In comparison with the previous study (LINDSTRÖM 1969) the bull sires contribution has increased at the expense of the bull dams. In comparison with theoretical studies (e.g. SKJERvold and LANGHOLZ 1964 a. b.; LINDHÉ 1968) the contribution of the bull sires is, however, still not optimal, that of the cow sires is too small and that of the bull dams too large.

\section{Speeding up progress}

Even if the noted annual genetic change is rather satisfactory, keeping in mind that selection has also been carried out for other traits than milk yield, there is no doubt that the rate of progress could be increased. One way 


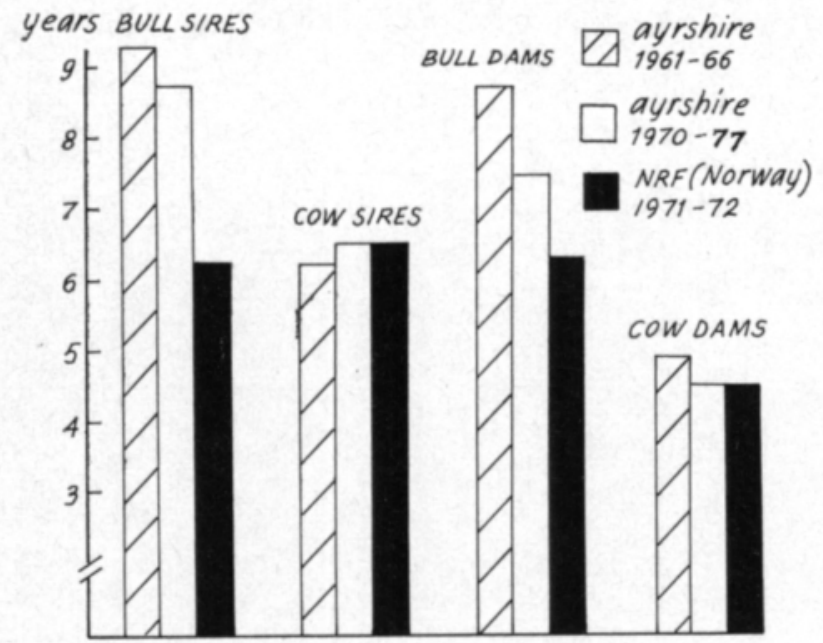

Fig. 3. Average age of parents of next generation.

of achieving this would be by cutting down on the long generation interval, which on the average was 6.8 years. As can be seen from Fig. 3. the bull sires are still in Finland almost two years older than in Norway. Also our bull dams are older. With the same generation interval here as in Norway the genetic progress would have been accelerated by c. $16 \%$.

It should also be possible to use the various bull groups more systematically, and thereby to increase the selection differential in the sire - cow path. From Table 5. it is apparent that even in recent years approximately $20 \%$ of the pregnancies have been by young untested bulls, used for up to $2-3$ years after they should have been "laid off». In this respect the situation resembles the one we had when using fresh semen. One reason for using a young bull in several consecutive years is the poor record recovery rate of inseminations done in milk recorded herds. Recent surveys indicate that only $6-8 \%$ of the inseminations done in recorded herds with semen from young bulls result in progeny tested daughters. Therefore each bull is generally used for an extended period and to a fairly large number of cows $(>2000)$. In addition many A.I. societies have used young bulls also outside recorded herds, thereby increasing their share of all inseminations and decreasing the usage of proven bulls. This latter practice, although in many ways justified from a genetic point of view should, however, be restricted only to the latest young bull cat-

Table 5. Usage of bull groups of different ages in 1976-77.

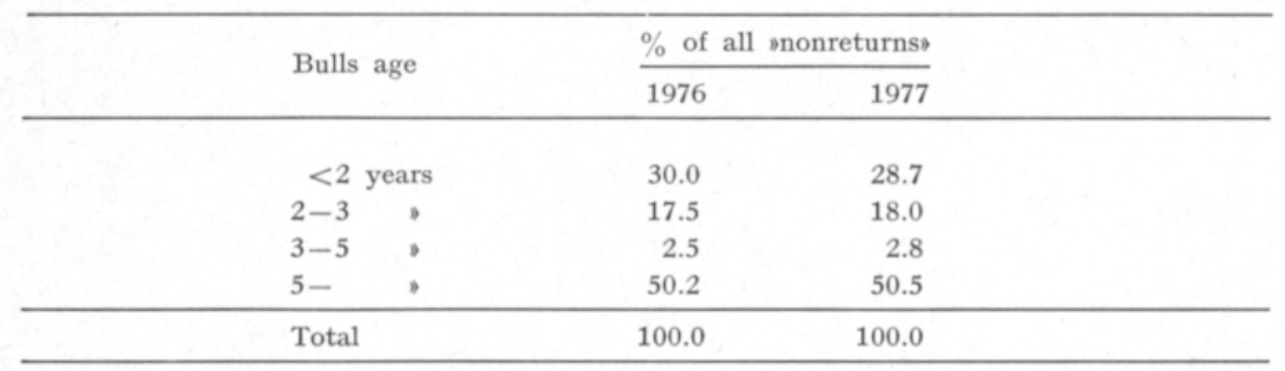


egory (bulls $1-2.5$ years of age). An improvement of the record recovery rate together with a more rational bull usage could easily boost the selection intensity in the sire $\rightarrow$ cow path by $25-35 \%$. Altogether it should not be too difficult to increase the annual genetic change by some $20 \%$.

\section{REFERENCES}

Anon. 1974. Board of Agriculture. Statistics of the activity of milk recording societies in Finland 1972-73. No. 378. Helsinki.

Anon. 1970-77. Keinosiemennysyhdistysten Liitto r.y. Vuosikert. 1970-76. (Central Assoc. of AI Societ. in Finland. An. Rep. 1970-76).

Averdunk, G. \& Lederer, J. 1974. Realisierter Zuchtfortschritt beim Fleckvich in Bayern. Fleckvieh-Kurier 1974, 1:4-7.

Hargrove, G. L. \& Legates, J. E. 1971. Biases in dairy sire evaluation attributable to genetic trend and femaleselection. J. Dairy Sci. 54: 1041-1051.

Hausman, J. 1968. Genetic improvement of the Israeli-Friesian dairy breed. Atti II. Symp. Intern. Zootechnol. Milan 1967: 194-195.

Johnson, D. G., Young, C. W., Touchberry, R. W. \& Steurnagel, G. R. 1976. Genetic change in Minnesota Holstein herds. J. Dairy Sci. 59:293-296.

LiNDHÉ, B. 1968. Model simulation of AI breeding within a dual purpose breed of cattle. Acta Agr. Scand. 18: 33-41.

LindströM, U. B. 1969. Genetic change in milk yield and fat precentage in artificially bred populations of Finnish dairy cattle. Acta Agr. Fenn. 114.

- , Maijala, K. \& Varo, M. 1973. Dairy progeny testing in Finland. J. Scient. Agric. Finl. 45: 565-571.

- , SirkкомaA, S. 1977. Comparisons of dairy progeny tests for sires and sons. Livestock Production Sci. 4: 45-55,

Majuala, K. 1969. Finnish Animal Husbandry. Publ. by Representatives of Finnish Animal Breeding Associations. 102 p. Helsinki.

Petersen, P. H., Gjøl-Christensen, L. Bech-Andersen, B. \& Ovesen, E. 1974. Economic optimisation of the breeding structure within a dual-purpose cattle population. Acta Agr. Scand. 24: 247-259.

Powell, R. L. \& Freeman, A. E. 1974. Genetic trend estimators. J. Dairy Sci. 57: 1067-1075.

Robertson, A. \& ReNdel, J. M. 1950. The use of progeny testing with artificial insemination in dairy cattle. J. Genet. 50: 21-31.

RUEgSegger, A. 1975. Nachzuchtsprüfungsergebnisse hinsichtlich Milchleistung, Melkbarkeit und Fleischleistung. Mitteil. Schweizer. Fleckviehzuchtverbandes 1975, 3:2-16.

Schaeffer, L. R., Freeman, M. G. \& Burnside, E. B. 1975. Evaluation of Ontario Holstein dairy sires for milk and fat production. J. Dairy Sci. 58 (1): 109-115.

ŠILER, R. \& ŠEREDA, L. 1976. Estimation of genetic gain in Gzech Red Pied cattle. First World Congr. Gen. Appl. Livestock Production 3: 783-787.

SKJERvold, H. \& LANGHolz, H.-J. 1964 a. Factors affecting the optimum structure of AI breeding in dairy cattle. Z. Tierzüchtung und Züchtungsbiol. 80: 25-40.

- 1964 b. Der optimale Einsatz der Nachkommenprüfstationen in der Züchterischen Arbeit. Z. Tirzüchtung und Züchtungsbiol. 80: 197-207.

- 1967. Selection schemes in relation to artificial insemination. Rep. Proc. Inv. Pap. 9th Intern. Congr. Animal Production. (1966): 250-261.

Syrstad, O. 1974 a. Avlsmessig framgang for mjølkeavdrått innen NRF. (Summary: Genetic progress for milk production in the Norwegian Red Breed). Meld. Norges Landbrukshøgskole 53, 14.

- 1974 b. A note on two methods for estimation of genetic change. Livestock Production Sci. $1: 47-51$.

Ms received October 17, 1978 


\section{Valinnan vaikutus AY-rodun maidontuotantoon Suomessa vuosina 1970-1977}

U. B. Lindström

Maatalouden Tutkimuskeskus, Kotieläinjalostuslaitos, 01300 Vantaa 30

Keinosiemennykseen valittujen sonnien vanhempien tuotantotietojen sekä ks-sonnien käytön perusteella jakson 1970-76 maidontuotannon perinnöllinen edistyminen arvioitiin hieman alle $1 \%$ :ksi vuosittain. Kahtena viimeisenä vuotena edistyminen oli $1.1 \%$ vuodessa. Jalostuksellista tehoa ovat heikentäneet sonnien korkea keski-ikä (pitkä käyttöaika) sekä turhan suuren ja laadultaan epätasaisen sonnijoukon käyttäminen. Perinnöllisestä kokonaisedistymisestä vastasi sonninisien valinta $43 \%$ :sta, sonninemien $37 \%$ :sta, lehmänisien $12 \%$ :sta ja lehmänemien (karjan sisällä tapahtuva valinta) $8 \%$ :sta. Käyttämällä jälkeläisarvosteltuja sonneja suunnitelmallisemmin, luopumalla ryhmäjalostuksen väärästä soveltamisesta ja nopeuttamalla nuorten sonnien käyttöä voitaisiin jalostuksellista edistymistä helposti parantaa $20-25 \%$. 